\title{
The Information Service in Developing the Students' Discipline Associated to the Utilization of School Canteen
}

\author{
Andrian Novialdi ${ }^{1}$, Prayitno ${ }^{1}$, Marjohan ${ }^{1}$ \\ ${ }^{1}$ Universitas Negeri Padang \\ Corresponding Author: andrian_novialdi@yahoo.com
}

\begin{abstract}
This research begins from the condition of students' discipline associated to the utilization of school canteen. The aim of the research is to obtain an overview regarding the information services provided by the guidance and counseling teachers. The background of the research is about the students' discipline associated to school canteen, condition and role of school canteen and also the role of guidance and counseling service particularly information service. The research used a descriptive quantitative method. Then, the population was the principal, guidance and counseling teachers, and students in Padang City Vocational School who were selected by using the purposive sampling technique. The research findings are: 1) the condition and role of school stalls according to the opinion of principal are in good category and according to the opinion of guidance and counseling teachers are in good enough category. 2) Students' disciplin in the utilization of school canteen according to the opinion of guidance and counseling teachers are good, meanwhile the student' opinions are good enough category. 3) The implementation of information services associated to the utilization of school canteens according to guidance and counseling teachers and students is in the good category.
\end{abstract}

Keywords: School Canteen, Students' Discipline, Information Service

\section{Introduction}

The quality of education can be recognized from the discipline of each individual or student both in the school environment and social environment. Learning is one of the factors which can improve the quality of human resources. Nowadays, the government through Vocational High School Education tries to create the skilled graduate and ready to enter the workforce. Through vocational high school, the graduates are required to have the competent skills in their fields so that they will be able to compete in the industrial world. To achieve the demand, a good learning process is needed. The efforts of school to create a good learning process enforce school rules so the students become disciplined. School rules are the collection of rules that must be obeyed or implemented at school by all students so that the learning process runs smoothly. School rule is as a must to be obeyed by the students which has aim to make students accustomed to obey the rules and make the students being disciplined by themselves (Eka S. Ariananda, 2014). 
The government regulation of the Republic of Indonesia no. 15 of 2005 concerning the national educatiom standard in article 42 paragraph 2 states that each education unit is required to have facilities and infrastructure including school canteen.

Related to explabation above, school canteen has an important role in realizing health messages and determining students' daily eating behavior through the provision of snacks. It can provide food as a substitute for breakfast and lunch at home, as well as snacks and drinks that are healthy, safe, and nutritious. Its existence plays an important role because it is able to provide $\pm 1 / 4$ family food consumption owing to the long study hour spent by student in school. School canteen which meets health standards has been considered one of the indicators of healthy schools (Nuraida, 2009).

Directorate SPKP of Deputy III (Badan POM RI, 2012) states the role of canteen in schools as follows: (1) Providing safe, quality and nutritious foods and beverages, and (2) Supporting the students' entrepreneurship education from an early age by providing snacks at cost-efficient prices, (3) Providing supporting knowledge on food and nutrition security to students, and (4) teaching the students to apply hygiene standards in handling, processing, and serving the foods in their daily life.

Therefore, the right utilization of school canteens by students requires adequate cooperation between the school and canteen owners, the school made the rules and policies about the development of school canteen associated to the utilization by the students. The implementation of rules and policies made by the school needs the students' discipline to do.

The implementation of good discipline in daily life begins from personal discipline. Personal discipline is influenced by two factors; internal and external factors. External factors are in the form of environment, while the internal factors are self-awareness. Based on these statement, school canteen can also be useful for students to practice their self-discipline habit in terms of what to eat, when to come and how to communicate between students and the staff of shool canteen(Wardiman,in Tu'u, 2004)

Besides, school canteen are often used as a smoking area or canteen owned by local communities around the school. Some students deliberately skip classes for a minute or find excuses to go out of class and sneak into a canteen near the school so they can smoke (Marjohan, 2009). Students who violate school rules such as late, truant, jump the fence, leave the class, then they use school canteen as hiding place.

The process of implementation of discipline in behavior for students is regulated by rules which are implemented and supervised directly by guidance and counseling teachers. The assessment criteria for evaluating violations of school rules are determined through the results of meeting of guidance and counseling teacher and the deputy head of student sector, which contains the level of attendance, personality, and criminal behavior. Through these assessment, the data of students who did violations were obtained, and further can be used by guidance and counseling teacher to help overcoming the problem through guidance and conseling service program (Abu Bakar, 2013)

The guidance and counseling services with emphasis from the Ministry of Education and Culture Number 81.A of 2013, Curriculum Implementation in Appendix IV Section VIII, clearly explains that "the guidance and counseling services lead to basic service,fulfilling the students' elementary needs; food, drink, fresh air, health, and socio-emotional needs" (Prayitno, Mungin, Marjohan, Heru, \& Ifdil, 2014).

Teachers play a role in educating, guiding, and directing students in choosing, buying, and consuming foods with the right nutrition requirements. Similarly, the guidance and counseling teacher can play a role in developing student's discipline associated with 
activities in school canteen, and what foods can be consumed efficiently and effectively through information given (Directorate General of Mother and Child Health and Nutrition, 2011).

The implementation of information services has been carried out by the guidance and counseling teachers or counselors, though it's yet to be optimized. This means that the students' attitudes towards school discipline are still very weak. Thus, adequate information services is required using additional media and methods (Nory Natalia in Tohirin, 2015)

This research aims to obtain an overview of the information services required in developing students' discipline in using school canteen. It specifically aims at obtaining an overview of the followings: (1) The condition of students' discipline associated to school canteen, (2) The role of school canteen toward the school rules, and (3) The role of the guidance and counseling services, especially information services toward the students' discipline associated to school canteen.

\section{Methods}

This research was a descriptive quantitative. This descriptive reseach aims to describe systematically, factual, and accurate of the facts ofparticular population or try to describe the phenomena in detail (A.Muri Yusuf, 2014:62).It also describes the information services of guidance and counseling in developing students' discipline associated to the utilization of school canteen, analyzed by statistical procedure.

The population of this research is the principal, guidance and counseling teachers, and students of Vocational High School of Padang City. The research uses the purposive sampling techniques, in which samples were determined through the following considerations: (a) the accreditation of Vocational High School of Padang City is A, because it is very well that is classified from the standards set by BAN S/M (National Board of Accreditation for Schools and Madrasah). (b) The number of school canteen is the most one, because this research is related to the development of students' discipline associated to school canteen. (c) class XI is taken, by considering class $\mathrm{X}$ is still in adjustment processand class XII is not permitted by the school because it willface final examination and national examination. The technique of data collection is by using questionnaire in order to determine the condition of school canteen, students' discipline and information service levels in which the results are analyzed based on the mean score and confirmed as very good, good, good enough, not good, not very good (Purwanto, 2007).

\section{Result \& Discussion}

The research data obtained from administering instrument samples were 2 principals, 12 guidance and counseling teachers, and 66 students.

\section{School Canteen}

The conditions and roles of school canteen are measured from several aspects, as stated in the indicators with the respondent of principal and guidance and counseling teachers. The results are as follows: 
Table 1. Conditions and Role of School Canteen

\begin{tabular}{|c|c|c|c|c|c|}
\hline \multirow[t]{2}{*}{ No } & \multirow[t]{2}{*}{ Respondent } & \multicolumn{2}{|c|}{ Principal } & \multicolumn{2}{|c|}{$\begin{array}{c}\text { Guidance and } \\
\text { Counseling } \\
\text { Teachers }\end{array}$} \\
\hline & & SMK I & SMK II & SMK I & SMK II \\
\hline 1 & Amount of respondent & 1 & 1 & 6 & 6 \\
\hline 2 & The lowest-highest score & 56 & 58 & $43-56$ & $\begin{array}{l}57,5- \\
66,25\end{array}$ \\
\hline 3 & Mean & 70 & 72,5 & 48,5 & 49 \\
\hline 4 & SD & - & - & 3,848 & 3,098 \\
\hline 5 & Category & G & G & GE & GE \\
\hline
\end{tabular}

Chart 1. Result of the Mean Score of School Canteen

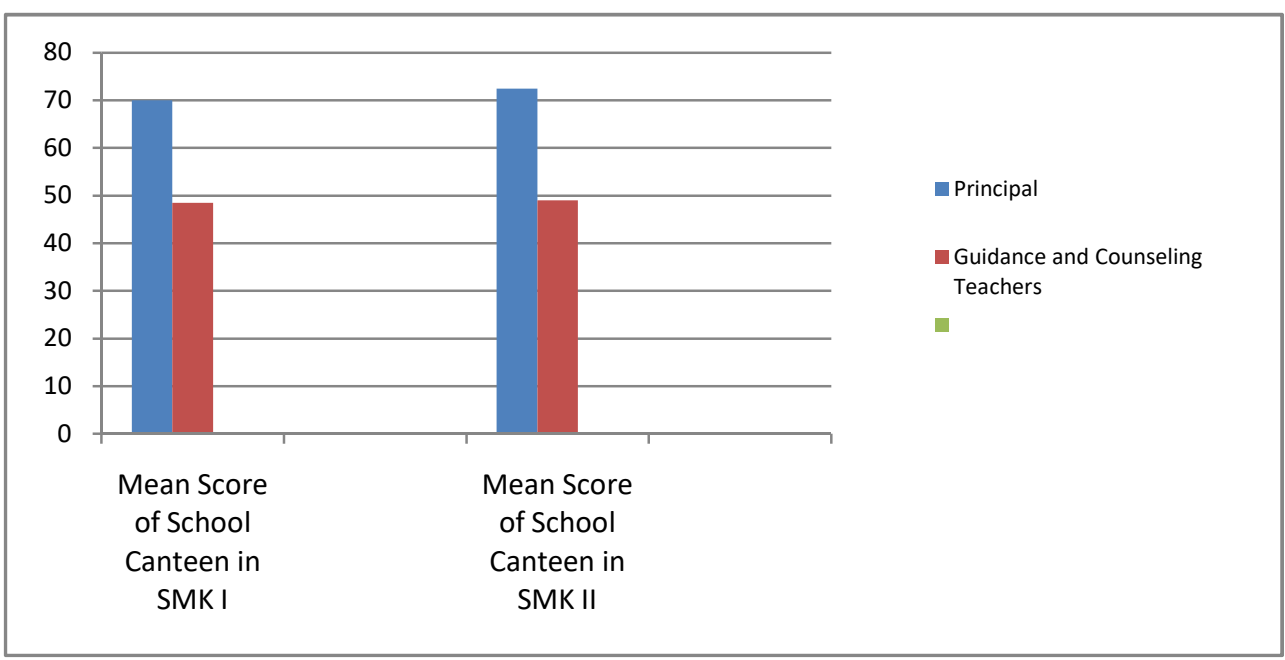

The condition and role of school canteen can be concluded based on the opinion of principal of SMK II which is $58(72.5 \%)$ higher than the principal of SMK I with $56(70 \%)$. However, both are in the same good category. Based on the respondent, the guidance and counseling teacher of SMK II is $49(61,25 \%)$ higher than the guidance and counseling teacher SMK I with a 48.5 (60.63). Both of them are the same good enough category.

Based on the condition and role of school canteen, the principal states good and guidance and counseling teachers state good enough, the results given by the principal and guidance and counseling teacher show the role and condition of school canteen did not run optimal, in which the condition and role of shool canteen can achieve very good category by hoping the school leader can pay attention to the implementation of canteen management as the important thing to do.

\section{Students' Discipline}

\section{Students' Discipline Using School Canteen}

The students' discipline using school canteen is measured from several aspects, as stated in the indicators with the respondents of guidance and counseling teacher and students, the results are as follows: 
Table 2. The Students' Discipline using School Canteen

\begin{tabular}{|l|l|c|c|c|c|}
\hline No & \multicolumn{1}{|c|}{ Respondent } & \multicolumn{2}{|c|}{$\begin{array}{c}\text { Guidance and } \\
\text { Counseling } \\
\text { Teachers }\end{array}$} & \multicolumn{2}{c|}{ Student } \\
\cline { 3 - 6 } & \multirow{2}{*}{ Element } & SMK I & SMK II & SMK I & SMK II \\
\hline 1 & Amount of respondent & 6 & 6 & 27 & 27 \\
\hline 2 & The lowest-highest score & $52-70$ & $49-68$ & $42-61$ & $41-74$ \\
\hline 3 & Mean & 59,17 & 59 & 51,56 & 54,89 \\
\hline 4 & SD & 6,494 & 8,099 & 6,668 & 7,051 \\
\hline 5 & Category & G & G & GE & G \\
\hline
\end{tabular}

Chart 2.Result of the Mean Score of Students' Discipline

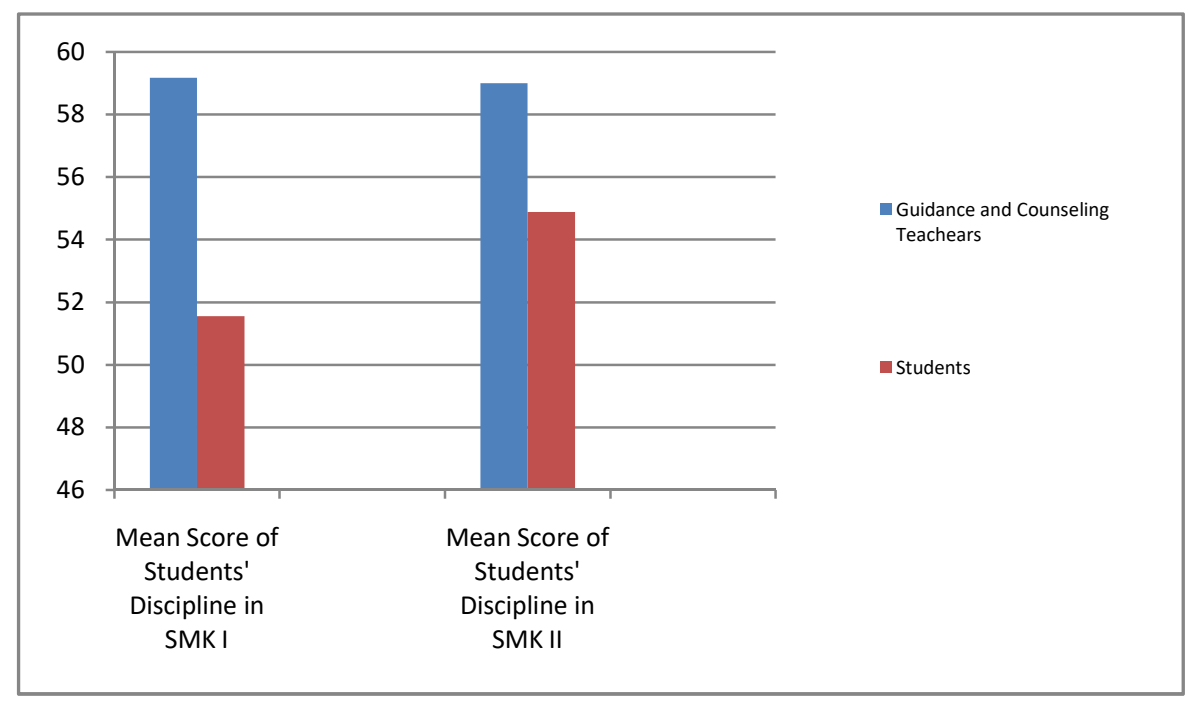

The students' discipline using school canteen based on the respondent of guidance and counseling teacher of SMK I is $59.17(74 \%)$ and slightly higher than the guidance and counseling teacher of SMK II which is 59 (73.75\%), with each school in the good category. On the other hand, based on the opinion of students in SMK I is $51.56(64.4 \%)$ lower than those in SMK II which is 54.89 (68.61\%), each school is in different category, where SMK I is good enough and SMK II is good.

The explanation above cab be concluded that students' discipline using school canteen based on the opinion of guidance and counseling teacher is in good category, while there is difference opinion between students of SMK I and SMK II, the students ofSMK I are in good enough category and students of SMK II are good. Based on the opinion of guidance and counseling teacher and students, this matter shows there are the students' attitude and behaviour who did not have high self-awareness in utilization of school canteen, such as buying food, drinks or meals, in appropriate utilization of schoold canteen on lesson hours, and honesty when buying foods and drinks, and also ignored the information from guidance and counseling teacher to bring provision to school.

\section{Information Service}

Information services associated to school canteen are measured from several aspects, as stated in the indicators with the respondent being the guidance and counseling teacher and students. The results are as follows: 
Table3. The Students' Opinion about Information Services related to School Canteen which have been given by Guidance and Counseling Teachers

\begin{tabular}{|l|l|c|c|c|c|}
\hline No & \multicolumn{2}{|c|}{$\begin{array}{c}\text { Respondent } \\
\text { Element }\end{array}$} & \multicolumn{2}{|c|}{$\begin{array}{c}\text { Guidance and } \\
\text { Counseling } \\
\text { Teachers }\end{array}$} & \multicolumn{2}{c|}{ Students } \\
\cline { 3 - 6 } & & SMK I & SMK II & SMK I & SMK II \\
\hline 1 & Amount of respondent & 6 & 6 & 27 & 27 \\
\hline 2 & The lowest-highest score & $48-65$ & $56-60$ & $44-71$ & $45-71$ \\
\hline 3 & Mean & 57,83 & 58,5 & 56,85 & 61,11 \\
\hline 4 & SD & 6,555 & 1,643 & 6,407 & 6,941 \\
\hline 5 & Category & G & G & G & G \\
\hline
\end{tabular}

Chart 3. Result of the Mean Score of Information Services

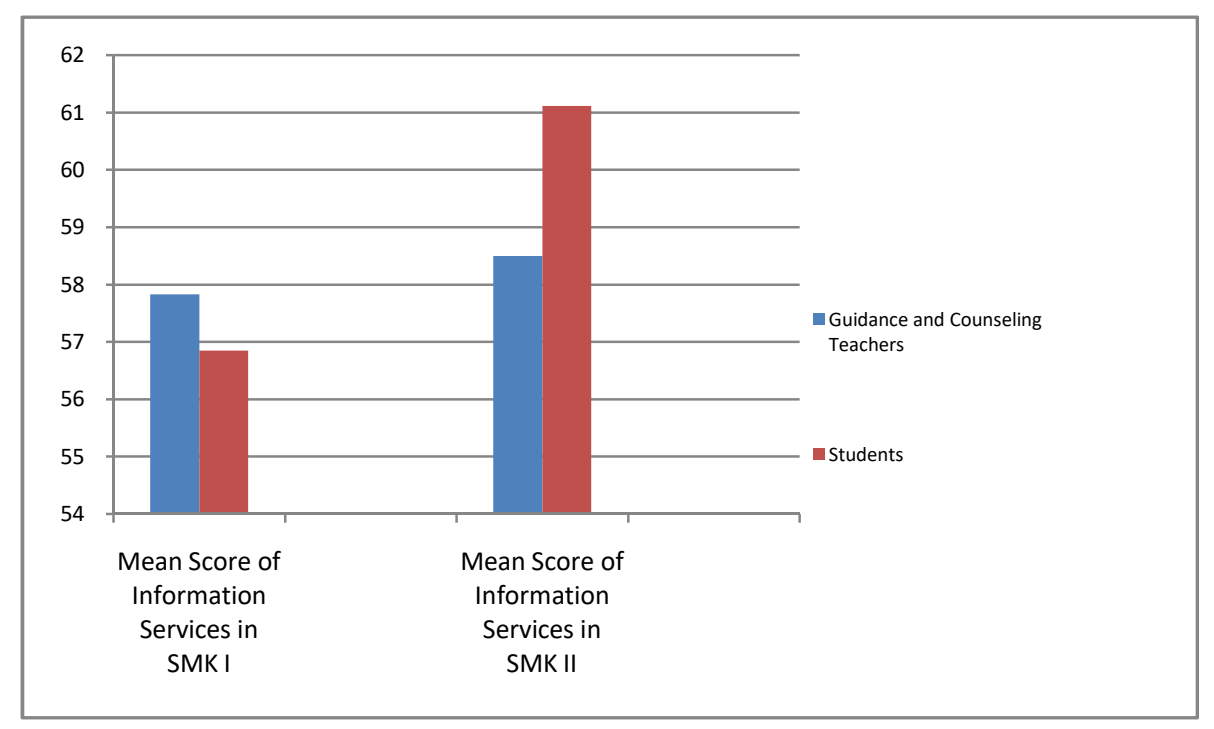

Based on the respondents results from the information services associated to school canteen,itcan be concluded that the average the guidance and

Information services associated to the utilization of school canteen based on the respondent of guidance and counseling teacher of SMK I is $57.83(72.29 \%)$ lower than those of SMK II teacher which is $58.5(73.13 \%)$, both of them are in the same good category. While based on the students of SMK I is 56.85 (71.06\%) lower than those of SMK II which is 61.11 $(76.38 \%)$, with both in the same good category.

The impelmentation of information services associated to school canteen which has been given by the guidance and counseling teacher is in good category. This matter explains that information services need to be given in order the students get the information related to the school canteen. to increase the quality of information service in accordance with the expectation of guidance and counseling service. Thus, the guidance and counseling teachers need to pay attention again to the granting of implementation of information service associated to the utilization of school canteen which become one of the service topics that must be given continuously.

\section{Discussion}

The results of the data analysis showed that overall information services in developing students' discipline associated to the utilization of school canteen conditions are 
seen from three variables, namely: (1) the school canteen, (2) the students' discipline, and (3) the information services. The following section discusses the variable analyzed in this research.

\section{Conditions and Roles of School Canteen}

As seen from the conditions and role of school canteens in two schools, and in accordance to the analysis of both Principals (SMK II and SMK I), both are in the good category. Meanwhile, according to the guidance and counseling teacher, the difference is good enough and not significant. This is in line with the main instruments for administering school canteen, namely: "school canteen is formed at the request of the school, with cooperation from the institution and the local health office regarding food and beverage inspection. This shows that the school has made efforts to ensure its canteens are in accordance with the conditions and roles should be, in accordance with the regulation of the directorate SPKP Deputy III(Badan POM RI, 2012).

\section{Students' Discipline Using School Canteen}

The students' discipline using school canteenbased on the opinion of guidance and counseling teacher in SMK I and SMK II has been in good category. While based on the students, it is good enough category. It means, the students have had discipline in utilization of school canteen. Therefore, the implementation of great discipline in daily life begins from personal discipline which is influenced by external and internal factors such as the environment and elf-awareness (Wardiman, in Tu'u, 2004)

This confirms that to build the students' discipline associated to the utilization of school canteen needs to self-awareness with reference to the existing regulation at school and needs ongoing supervision by teachers to build students' discipline.

\section{Information services associated to school canteen that have been given by the guidance and counseling teachers}

The implementation of information services by the guidance and counseling teachers associated to school canteen provides information on the importance of honesty when buying food or leaving trash indiscriminately because snacks should be disposed of in trash cans, another information related to the importance of bringing provisions from home, and other important information associated to school canteen. Generally, the information has been good given by the guidance and counseling teacher for the students. Next, the implementation of information service related to the utilization of school canteen according to the guidance ans counseling teachers in both schools shows there is no significant differences. It means, the guidance and counseling teachers at SMK I and SMK II are not too different in explaining the information. While the students' opinion in both schools about the information service given by guidance and counseling teachers shows there are significant differences between the needs of the two schools, namely SMK II is better than SMK I. This is in line with students' opinion that the guidance and counseling services in SMK II is significantly better than SMK I.

Meanwhile, there is relationship between information service with students' discipline and school canteen. It means, the better implementation of information service by guidance and counseling teacher can influence significantly students' discipline in utilization of school canteen. 


\section{Conclusion}

The result of analysis showed that the overall information services in developing students' discipline associated to the utilization of school canteen, in the term of condition and role of school canteen in Padang vocational high school showed that the need for more attention towards the implementation of school canteen management by the principal and supervision by the guidance and counseling teacher to the students. Meanwhile, the same condition for the students' discipline in utilization of school canteen, the students need ongoing discipline development associated to utilization of school canteen. The implementation of information services associated to utilization of school canteen which has been provided by the guidance and counseling teacher needs an increase of the quality of service given, because the better the information services provided, the better the utilization of schol canteen by the students.

\section{Reference}

Abu Bakar M. Luddin. 2013. "Kinerja Kepala Sekolah dalam Kegiatan Bimbingan dan Konseling". Jurnal Ilmu Pendidikan, Jilid 19, Nomor 2, Desember 2013, hlm. 218-224.

Badan POM RI. (2012). Keamanan Pangan di Kantin Sekolah. Jakarta: Direktorat SPKP Deputi III.

Directorate General of Mother and Child Health and Nutrition. (2011). Pedoman Keamanan Pangan di Sekolah Dasar. In Pedoman Keamanan Pangan di Sekolah Dasar. Jakarta.

Dewi Setyaningrum, Denok Setiawati. 2013. “Pengaruh Persepsi Siswa tentang Layanan Konseling Individu dan Persepsi tentang Kompetensi Kepribadian Konselor terhadap Minat Memanfaatkan Layanan Bimbingan dan Konseling". Jurnal BK UNESA. Volume 01 Nomor 01 Tahun 2013, 245- 252.

Eka S. Ariananda, Syamsuri Hasan, Maman Rakhman. 2014. “Pengaruh Kedisiplinan Siswa di Sekolah terhadap Prestasi Belajar Siswa Teknik Pendingin". Departemen Pendidikan Teknik Mesin Universitas Pendidikan Indonesia.Journal of Mechanical Engineering Education, Vol.1, No.2, Desember 2014.

Keputusan Menteri Kesehatan RINO: 1429/MENKES/SK/X11/2006. PedomanPenyelenggaraanKesehatanLingkunganSekolah.

Marjohan. (2009). School Healing. Yogyakarta: Pustaka Insan Madani.

Natalia, N., Firman, F., \& Daharnis, D. (2015). Efektivitas Layanan Informasi dengan Menggunakan Media Audio Visual dalam Meningkatkan Sikap Siswa terhadap Kedisiplinan Sekolah. Jurnal Konseling Dan Pendidikan. https://doi.org/10.29210/112800

Nuraida, Kusumaningrum, H., Sri, N., Koswara, S., Zulaikhah, S. M., Madjid, S., ... Triwahyunto, A. (2011). Menuju Kantin Sehat di Sekolah (Widaninggar Widjajanti, N. Siregar, \& J. Hutapea, eds.). Jakarta: DITJEN Pendidikan Dasar Kementerian Pendidikan Nasional.

Peraturan Pemerintah Republik Indonesia Nomor. 74 Tahun 2008 tentang Tugas Guru BK/Konselor dan Pengawasan Bimbingan dan Konseling.

Permendikbud Nomor 111 Tahun 2014 tentang Bimbingan dan Konseling pada Pendidikan Dasar dan Pendidikan Menengah. Jakarta: Kemendikbud RI. 
Prayitno, Mungin, Marjohan, Heru, \& Ifdil. (2014). Pembelajaran Melalui Pelayanan BK di Satuan Pendidikan. Padang: UNP Press.

Purwanto. (2007). Instrumen Penelitian Sosial dan Pendidikan. Yogyakarta: Pustaka Pelajar.

Tu'u, T. (2004). Peran Disiplin pada Perilaku dan Prestasi Siswa. Jakarta: PT Grasindo.

Yusuf, A. M. (2014). Metode Penelitian: Kuantitaif, Kualitatif dan Penelitian Gabungan. Padang: UNP Press. 